\title{
Heavy Metals Concentration in Facial Cosmetics
}

\author{
Aldayel $\mathrm{O}^{1}$, Hefne $\mathrm{J}^{2}$, Alharbi $\mathrm{KN}^{1^{*}}$ and Al-Ajyan $\mathrm{T}^{1}$
}

${ }^{1}$ King Abdulaziz City for Science and Technology, Riyadh, Saudi Arabia

${ }^{2}$ King Abdullah City for Atomic and Renewable Energy, Riyadh, Saudi Arabia

*Corresponding author: Alharbi KN, King Abdulaziz City for Science and Technology, Riyadh, Saudi Arabia, Tel: 966 555601381; E-mail: kalharbi@kacst.edu.sa

Received: November 05, 2017; Accepted: December 18, 2017; Published: January 12, 2018

Copyright: @ 2018 Aldayel O, et al. This is an open-access article distributed under the terms of the Creative Commons Attribution License, which permits unrestricted use, distribution, and reproduction in any medium, provided the original author and source are credited.

\begin{abstract}
Heavy metals impurities in cosmetic products are common due to their natural abundance. However, they should be kept to a minimum wherever technically feasible. Most people, specially females, use cosmetic and their ingredients on a daily basis. Although human external contact with a substance rarely results in its penetration through the skin and significant systemic exposure, cosmetics produce local (skin, eye) exposure and are used in the oral cavity, on the face, lips, eyes and mucosa. Therefore, human systemic exposure to their ingredients can rarely be completely excluded.

Because metals can induce unwanted side effects in humans, to establish their contents in body-care cosmetics is important for quality and health controls. In this work we have selected nine most expensive brands of facial cosmetics (Base jelly, Whitener, Sheen and Face powder) from the Saudi market. Twenty-eight elements were detected by using Inductively Coupled Plasma Mass Spectrometer (ICP-MS) and a flow injection mercury system (FIMS). The mean, maximum and minimum concentrations of each element are reported.
\end{abstract}

Keywords: Heavy elements; Cosmetics; Inductively coupled plasmamass spectrometry (ICP-MS); Flow injection mercury system (FIMS)

\section{Introduction}

Women are mainly used different cosmetic products of body care as a basic daily product and they are not aware of the dangers of heavy metals that contained in cosmetics. Even if cosmetic products have a tiny proportion of heavy metals; which, they could not be ignored as cosmetics are worn for a long period [1]. Thirty-five metals are of concern because of potential occupational or residential exposure; 23 of these are heavy metals: antimony, arsenic, bismuth, cadmium, cerium, chromium, cobalt, copper, gallium, gold, iron, lead, manganese, mercury, nickel, platinum, silver, tellurium, thallium, tin, uranium, vanadium, and zinc [2]. Trace amounts of these elements are common in our environment and diet and are actually necessary for good health, but large amounts of any of them may cause acute or chronic toxicity (poisoning). Heavy metal toxicity can result in damaged or reduced mental and central nervous function, lower energy levels, and damage to blood composition, lungs, kidneys, liver, and other vital organs. Long-term exposure may result in slowly progressing physical, muscular, and neurological degenerative processes that mimic Alzheimer's or Parkinson's disease, muscular dystrophy, and multiple sclerosis. Allergies are not uncommon and repeated long-term contact with some metals or their compounds may even cause cancer [3].

Lipsticks are one of the most important cosmetic product that women are commonly used to look more attractive and be in a good looking; however, they paid a high price by exposure to different heavy metals, which lipsticks are contained [1]. In 2007, the Campaign for Safe Cosmetics tested for and found-lead in numerous top-selling lipsticks [4]. It stood to reason that lipstick may not be the only product that could contain lead and not list it on the label. After reports revealed that several other countries such as Italy [5] Ireland [6] and Canada [7] found heavy metals in face paints.

Lead is harmful, particularly so to the developing brain and nervous system [6,8] Lead can cause kidney damage, has been linked to cardiovascular disease and can cause autoimmune disorders [9]. Lead mainly enters the body through ingestion or inhalation of lead-dust. Adults absorb about $11 \%$ while children absorb $30-75 \%$ of lead that reaches the digestive tract. Less than $1 \%$ of lead is known to be absorbed through the skin [10]. Lead poisoning is a global problem. It is one of the most important environmental diseases in children [11]. Pregnant women and children 6 years or younger absorb lead in the highest quantities. Even low levels of lead exposure are considered hazardous to pregnant women [12]. Lead exposure during the first trimester of pregnancy has been found to cause alterations in the developing retina, thus leading to possible defects in the visual system [13]. Lead poisoning has been linked to juvenile delinquency and behavioral problems. Young children are particularly susceptible to lead poisoning due to their normal hand-to-mouth activity and because of the high efficiency of lead absorption by their gastrointestinal tracts [14]. Chronic low-dose lead exposure was found to cause renal tubular injury in children [15], while in adults, it was associated with poorly controlled hypertension [16]. A blood lead level of $10 \mathrm{mg} / \mathrm{dl}$ is of concern [8]. Shaltout et al. [17] found 20 patients aged between 1 and 18 months suffering from lead encephalopathy in Kuwait. The blood levels in 19 children ranged between 60 and 257 $\mathrm{mg} / \mathrm{dl}$. Two of these patients died before starting treatment, and three children died during treatment. Among the children who recovered, four had neurological sequelae. The source of lead in 11 patients was confirmed to be kohl [17]. On another reference, a seven-month-old baby was found to have a blood lead level of $39 \mathrm{mg} / \mathrm{dl}$ due to use of kohl [18]. In the USA, kohl and 'kajal' from the Middle East were considered among the unapproved dyes in eye cosmetics that contained potentially harmful amounts of lead [19]. Similarly, certain 
traditional digestive remedies also contain harmful levels of lead [18]. Zakaria and Ho [1] studied lipsticks marketed in Malaysia for their heavy metal contamination. They have found lead concentrations of $0.8-15 \mathrm{mg} / \mathrm{kg}$. There is no internationally agreed limit on permissible lead contents of lipsticks; but Health Canada stipulates it should not exceed $10 \mathrm{ppm}$.

Little is known about lead poisoning in Saudi Arabia. Studies have suggested that kohl in Saudi Arabia might be a cause of lead toxicity, $[20,21]$ but no detailed investigation has been undertaken. The Saudi Standards, Metrology and Quality Organization issue a standard for the rouge samples, number 1871 in 2001. In this standard the concentration of As (as $\mathrm{As}_{2} \mathrm{O}_{2}$ ), $\mathrm{Pb}$ and $\mathrm{Hg}$ is limited to $2 \mathrm{mg} / \mathrm{Kg}, 20$ $\mathrm{mg} / \mathrm{Kg}, 1 \mathrm{mg} / \mathrm{Kg}$ respectively.

A certain degree of sensitization was shown by the salts of platinum group elements, i.e., $\mathrm{Pt}, \mathrm{Pd}, \mathrm{Rh}$, and $\mathrm{Ir}$, because of their large use in dental devices, jewellery, and automotive catalysts [22-24]. Moreover, a synergic action between $\mathrm{Pd}$ and $\mathrm{Ni}$, pertaining to the same periodic group, has been suggested as being the cause of cross-sensitization [22]. Both $\mathrm{Cu}$ and $\mathrm{Mn}$ are rare skin sensitizers; immune reactions due to $\mathrm{Cu}$ exposure from intrauterine devices or by handling euro coins have been described, whereas the use of prosthetic materials in dentistry has created a risk of sensitization for both $\mathrm{Cu}$ and $\mathrm{Mn}$ $[25,26]$. Considering toxic metals such as $\mathrm{Cd}$ and $\mathrm{Hg}$ little is known about their dermatological activities. Cases of allergic contact dermatitis (ACD) due to Cd exposure from cement dust emission [27] and ceramics material [28] and to Hg present as ammoniated mercury $\left(\mathrm{HgNH}_{2} \mathrm{Cl}\right)$ in skin lightening creams have been reported [29]. One case of sensitization to $\mathrm{V}$ was found in an enameller employed in the ceramics industry [28]. Another important way of skin exposure to metals is the use of cosmetic products such as moisturizing creams, lipsticks, eye cosmetics, shampoos, cleansing milk, henna dye, etc. In these make-up product metals are present as impurities due to the particular sample formulation or the release from metallic devices used during their manufacture. In fact, the European Communities Directive 76/768/EEC and further revisions banned the use of Cd, Co, $\mathrm{Cr}, \mathrm{Ni}$, and $\mathrm{Pb}$ as metallic ions or salts in the preparation of cosmetic formulations [30]. Considering the prolonged contact time of cosmetic products with the skin the risk of ACD might be increased [31,32]. As a support to this, there are several studies evidencing the presence of $\mathrm{Co}, \mathrm{Cr}, \mathrm{Ni}$, and $\mathrm{Pb}$ at levels of $\mu \mathrm{g} \mathrm{g}^{-1}$ in henna dye, eye shadows, and lip liners with frequent positive reactions to patch tests [31,33-36]. Some authors revealed the presence of $\mathrm{Cd}, \mathrm{Cr}, \mathrm{Cu}, \mathrm{Hg}, \mathrm{Pb}$, and metal oxides in body or sunscreen creams [37-39]. If the cosmetic products are formulated as dry, this will minimize the risk of skin penetration of metal, whereas those based on fat-soluble substances (for example moisturizing creams) promote the percutaneous absorption much more. On the other hand, adverse reactions to metal-containing cosmetic products were mostly observed in patients with manifestation of pre-existing allergy to metals [40]. Patch tests revealed that a threshold limit equal to $5000 \mathrm{ng} \mathrm{g}^{-1}$ or for a more protection equal to $1000 \mathrm{ng} \mathrm{g}^{-1}$ for $\mathrm{Ni}$, Co and $\mathrm{Cr}$ excluded the risk of elicitation in sensitized people $[39,40]$. Given these facts and the increased frequency of allergy to $\mathrm{Ni}$, the challenge of the cosmetic industry was to manufacture products to be used by people pre-sensitized to Ni. For this reason, manufacturers made available on the market creams labelled with the phrase "Ni-tested" together with a declared $\mathrm{Ni}$ concentration of $100 \mathrm{ng} \mathrm{g}^{-1}$, thus guaranteeing levels 50 times below the risk of causing allergy reactions [40].
There is increasing evidence that the chemical constituents of underarm and body-care cosmetics applied to the underarm and breast area may be involved in the rising incidence of breast cancer [41-43]. Aluminium salts, such as aluminium chlorohydrate $(\mathrm{ACH})$, are the active ingredients of antiperspirant [44]. Their mode of action is thought to involve blockage of the sweat ducts which prevents the escape of sweat onto the body surface, probably through the formation of a physical plug at the top of the sweat duct, which is composed of a combination of precipitated salts and damaged cells [44-47].

Because metals can induce unwanted side effects in humans establishing their contents in body-care cosmetics products is important for quality and health controls. The European Community directives forbid cosmetic formulations containing more than $1 \%$ selenium sulfide while zinc pyrithione cannot exceed $0.5 \%$ and other zinc salts are limited to $1 \%$ [48]. In this work, we have selected nine brands, which are the most expensive of the facial cosmetics (Base jelly, Whitener, Sheen and Face powder) from the Saudi market. Twentyeight elements were detected by using Inductively Coupled Plasma Mass Spectrometer (ICP-MS) and a flow injection mercury system (FIMS).

\section{Materials and Methods}

\section{Sample preparation}

An accurately weighed sample of (0.1-0.2 g) was transferred to a TEFLON digestion tube $(120 \mathrm{~mL})$ mixed with $7.0 \mathrm{~mL}$ of the acid mixture $\left(\mathrm{HNO}_{3} / \mathrm{HF} / \mathrm{HCl}, 4.5: 2: 0.5\right)$. The tube was sealed. The sample was digested in a microwave oven (Milestone ETHOS 1600) following a heating program shown in Table 1.

After cooling to ambient temperature, the tube was unsealed; the inside of the lid was rinsed with distilled and de-ionized water (DDW) and the mixture heated on a hotplate $\left(120^{\circ} \mathrm{C}\right)$ for $30 \mathrm{~min}$. to evaporate residual $\mathrm{HF}$ and $\mathrm{HCl}$. The resulting digest was filtered in a polypropylene flask using $1 \% \mathrm{HNO}_{3}$ and made up to $50 \mathrm{ml}$ volume. For ICP-MS measurement the clear digest obtained were diluted 10 times incorporating $10 \mu \mathrm{gL}^{-1}$ solution of ${ }^{103} \mathrm{Rh}$. In general, samples and standard reference materials (SRM) were prepared in a batch of six including a blank $\left(\mathrm{HNO}_{3} / \mathrm{HF} / \mathrm{HCl}\right)$ digest.

\begin{tabular}{|l|l|l|l|l|}
\hline Step & $\mathbf{1}$ & $\mathbf{2}$ & $\mathbf{3}$ & $\mathbf{4}$ \\
\hline Power/W & 400 & 0 & 300 & 400 \\
\hline Time/min & 15 & 2 & 10 & 15 \\
\hline Temp $/{ }^{\circ} \mathrm{C}$ & 195 & 195 & 195 & 195 \\
\hline
\end{tabular}

Table 1: Microwave heating program used for dissolution of the samples.

\section{Chemicals and reagents}

High purity water (DDW) (Specific resistivity 18 MW.cm ${ }^{-1}$ ) obtained from an E-pure water purification system (Barnsted, USA) was used throughout the work. $\mathrm{HNO}_{3}, \mathrm{HF}$ and $\mathrm{HCl}$ used for sample digestion were of Suprapureâ grade with certified impurity contents (Merck, Germany). A multi-element standard containing 27 elements were prepared from Perkin-Elmer single-element ICP standards (1000 or $10000 \mathrm{ppm}$ ). The Standard Reference Material (SRM), IAEA-SOIL-7 was purchased from the International Atomic Energy Agency, Vienna. 
Citation: $\quad$ Aldayel O, Hefne J, Alharbi KN, Al-Ajyan T (2018) Heavy Metals Concentration in Facial Cosmetics. Nat Prod Chem Res 6: 303. doi:

Page 3 of 9

\section{Instrumentation}

A Perkin-Elmer Sciex ELAN 6100 inductively coupled plasma mass spectrometer (ICP-MS), equipped with a quadruple mass filter, a cross-flow nebulizer and a Scott type spray chamber, was used for all measurements.

\section{Quality assurance}

To assess the analytical process and make a comparative analysis, Standard Reference Materials (Soil 7) from the International Atomic Energy Agency (IAEA), Vienna, Austria was used. The quantitative analysis result is shown in Table 2 . The results are generally in good agreement with certified values of the reference materials.

\begin{tabular}{|c|c|c|c|}
\hline Elements & Certified Values & Actual work & \\
\hline & $95 \%$ Confidence Interval in ppm & $\mathrm{ppm}$ & RSD \\
\hline $\mathrm{Li}$ & $15-42$ & 39.1 & 3.07 \\
\hline B & & 28.3 & 5.4 \\
\hline $\mathrm{Na}$ & $2300-2500$ & 2090 & 0.96 \\
\hline $\mathrm{Mg}$ & $11000-11800$ & 11200 & 1.05 \\
\hline $\mathrm{Al}$ & $44000-51000$ & 47900 & 0.287 \\
\hline $\mathrm{K}$ & $11300-12700$ & 11500 & 0.878 \\
\hline $\mathrm{Ca}$ & $157000-174000$ & 155000 & 1.09 \\
\hline $\mathrm{v}$ & $59-73$ & 73.7 & 0.982 \\
\hline $\mathrm{Cr}$ & $49-74$ & 62.8 & 3.33 \\
\hline $\mathrm{Mn}$ & & 648 & 1.13 \\
\hline $\mathrm{Fe}$ & $25200-26300$ & 25100 & 0.623 \\
\hline Co & $8.4-10.1$ & 12.4 & 4.32 \\
\hline $\mathrm{Ni}$ & $21-37$ & 17.2 & 2.22 \\
\hline $\mathrm{Cu}$ & $9.0-13$ & 11.2 & 1.16 \\
\hline $\mathrm{Zn}$ & $101-113$ & 115 & 0.0825 \\
\hline As & $12.5-14.2$ & 14 & 2.23 \\
\hline Se & $0.2-0.8$ & 1.3 & 34.6 \\
\hline $\mathrm{Rb}$ & $47-56$ & 50.2 & 0.327 \\
\hline $\mathrm{Sr}$ & $103-114$ & 102 & 1.35 \\
\hline Mo & $0.9-5.1$ & 1.03 & 3.47 \\
\hline $\mathrm{Ag}$ & & 0.484 & 3.3 \\
\hline $\mathrm{Cd}$ & $1.1-2.7$ & 1.13 & 0.726 \\
\hline $\mathrm{Ba}$ & $131-196$ & 131 & 1.36 \\
\hline $\mathrm{Pb}$ & $55-71$ & 61.7 & 0.262 \\
\hline U & $2.2-3.3$ & 2.07 & 0.544 \\
\hline $\mathrm{Sb}$ & $1.4-1.8$ & 1.57 & 1.91 \\
\hline Sn & & 2.84 & 2.79 \\
\hline
\end{tabular}

Table 2: Concentration of elements in Soil 7.

\section{Hg analyses}

A flow injection mercury system (FIMS) from Perkin Elmer FIMS-400 was used for determination of $\mathrm{Hg}$ in the samples.
The FIMS is a complicated technique depending up on synchronization of mechanical, chemical and optical operations. The system contains three major units namely the spectrophotometer coupled with the flow injection circuitry, the amalgamation unit and 
Citation: $\quad$ Aldayel O, Hefne J, Alharbi KN, Al-Ajyan T (2018) Heavy Metals Concentration in Facial Cosmetics. Nat Prod Chem Res 6: 303. doi:

Page 4 of 9

the computer unit for automated control of the operation and measurements. The FIAS program was optimized and the program is

saved as "Mercury 2" in the computer, Table 3. The FIMS pumps program is shown in Table 4.

\begin{tabular}{|l|l|l|l|}
\hline \multirow{2}{*}{ Method name: } & Type & Diameter & Time \\
\cline { 2 - 4 } & Mercury 2 & Slit width: & $0.7 \mathrm{~nm}$ \\
\hline Technique: & FIAS-MHS & Read time: & $15.0 \mathrm{~s}$ \\
\hline Wavelength: & $253.4 \mathrm{~nm}$ & Read Delay: & $0.0 \mathrm{~s}$ \\
\hline BOC time: & $2.0 \mathrm{~s}$ & Signal type: & AA \\
\hline Measurement: & Peak height & Calibration: & Linear, zero intercept \\
\hline
\end{tabular}

Table 3: FIMS program.

\begin{tabular}{|c|c|c|c|c|c|c|c|c|}
\hline Step & Time & Pump 1 speed & Pump 2 speed & Valve position & Read & Heat & Cool & Argon \\
\hline Pre-fill & 8 & 100 & 40 & Fill & & & $x$ & $x$ \\
\hline Step 1 & 5 & 100 & 40 & Fill & & $x$ & & $x$ \\
\hline Step 2 & 25 & 100 & 40 & Fill & & & $x$ & $x$ \\
\hline Step 3 & 20 & 0 & 40 & Inject & & & $x$ & $x$ \\
\hline Step 4 & 20 & 0 & 40 & Inject & & & $x$ & $x$ \\
\hline Step 5 & 10 & 0 & 40 & Fill & & & $x$ & $x$ \\
\hline Step 6 & 20 & 0 & 40 & Fill & $x$ & $x$ & & \\
\hline Step 7 & 10 & 0 & 40 & Fill & & & $x$ & $x$ \\
\hline Step 8 & 1 & 0 & 0 & Fill & & & & \\
\hline \multicolumn{9}{|c|}{ Steps to Repeat: 1 to 4} \\
\hline
\end{tabular}

Table 4: FIMS pumps program.

The blank used in this process contained $2 \mathrm{v} / \mathrm{v} \% \mathrm{H}_{2} \mathrm{SO}_{4}, 2 \mathrm{v} / \mathrm{v} \%$ $\mathrm{HNO}_{3}$ and approx. $1.0 \mathrm{mg} \mathrm{L}^{-1} \mathrm{KMnO}_{4}$ in de-ionized water. All the measuring standard and sample solutions were stabilized in the same medium.

\section{Results and Discussion}

Heavy metals are found naturally in the environment. They exist in manufactured pigments and other raw materials in all industries including cosmetics. Some of these metals have been used as cosmetic ingredients in the past. Examples include the preservative thimerosal (mercury), the progressive hair dye lead acetate and a number of tattoo pigments such as red cinnabar (mercuric sulfide) [49]. The concentration of twenty elements in $\mathrm{ppb}(\mu \mathrm{g} / \mathrm{Kg})$ in the facial cosmetics (Base jelly, Whitener, Sheen and Face powder) of nine brands of facial cosmetics. In addition, the mean, the minimum and the maximum of elemental concentration are reported in Tables 5-8. Inductively Coupled Plasma Mass Spectrometer (ICP-MS) and a flow injection mercury system (FIMS) were used to obtain the results.

\begin{tabular}{|l|l|l|l|l|l|l|l|}
\hline Elements & \multicolumn{9}{|c|}{ Base jelly } \\
\hline & Mean of nine brands & Min & RSD & Samples & Max & RSD & Samples \\
\hline Li & 14875.5 & 29.2 & & C46 & 39900 & 0.57 & C55 \\
\hline B & 11080.0 & BDL & & C37, C46, C55, C63 and C71 & 17600 & 12.9 & C26 \\
\hline $\mathrm{Na}$ & 2941444.4 & 353000 & 1.59 & C37 & 13000000 & 0.79 & C1 \\
\hline Mg & 2029900.0 & 35100 & 2.45 & C46 & 9970000 & 0.61 & C9 \\
\hline Al & 3661444.4 & 333000 & 1.06 & C71 & 10200000 & 0.61 & C9 \\
\hline
\end{tabular}


Citation: $\quad$ Aldayel O, Hefne J, Alharbi KN, Al-Ajyan T (2018) Heavy Metals Concentration in Facial Cosmetics. Nat Prod Chem Res 6: 303. doi:

Page 5 of 9

\begin{tabular}{|c|c|c|c|c|c|c|c|}
\hline $\mathrm{K}$ & 987422.2 & 57800 & 3.37 & C1 & 4650000 & 0.69 & C9 \\
\hline $\mathrm{Ca}$ & 133399.6 & BDL & & $\mathrm{C} 17, \mathrm{C} 37, \mathrm{C} 46$ and C55 & 434000 & 2.29 & $\mathrm{C} 26$ \\
\hline V & 694.4 & 198 & 1.97 & $\mathrm{C} 26$ & 1590 & 0.83 & $\mathrm{C9}$ \\
\hline $\mathrm{Cr}$ & 3853.3 & 1150 & 4.85 & $\mathrm{C} 17$ & 12800 & 1.89 & C71 \\
\hline $\mathrm{Mn}$ & 9200.0 & 3610 & 1.3 & $\mathrm{C} 37$ & 13800 & 0.81 & $\mathrm{C} 26$ \\
\hline $\mathrm{Fe}$ & 8464444.4 & 1300000 & 1.54 & $\mathrm{C} 63$ & 17300000 & 0.32 & C1 \\
\hline Co & 932.8 & 204 & 2.14 & $\mathrm{C} 63$ & 2070 & 2.41 & C71 \\
\hline $\mathrm{Ni}$ & 7539.4 & BDL & & C9 and C55 & 26100 & 0.98 & $\mathrm{C} 71$ \\
\hline $\mathrm{Cu}$ & 21368.9 & 8020 & 2.06 & C9 & 34700 & 0.55 & C46 \\
\hline $\mathrm{Zn}$ & 58855.6 & 21900 & 2.72 & C9 & 101000 & 0.36 & C46 \\
\hline As & 387.1 & 82.1 & & $\mathrm{C} 71$ & 1240 & 1.78 & $\mathrm{C} 26$ \\
\hline Se & 225.2 & 37.2 & & $\mathrm{C} 26$ & 582 & 16 & C46 \\
\hline $\mathrm{Rb}$ & 6241.9 & 88.1 & 7.63 & C46 & 35800 & 1.47 & C9 \\
\hline $\mathrm{Sr}$ & 4351.4 & 262 & 6.01 & $\mathrm{C} 46$ & 13400 & 0.26 & C37 \\
\hline Mo & 310.6 & 90.1 & 2.25 & $\mathrm{C} 26$ & 662 & 3.6 & C71 \\
\hline $\mathrm{Ag}$ & 141.3 & 13.1 & & $\mathrm{C} 37$ & 499 & 2.69 & $\mathrm{C} 71$ \\
\hline $\mathrm{Cd}$ & 12.0 & 1.99 & & C71 & 38.2 & 10.2 & C46 \\
\hline $\mathrm{Ba}$ & 101979.6 & 966 & 1.67 & $\mathrm{C} 1$ & 884000 & 0.47 & C9 \\
\hline $\mathrm{Pb}$ & 2024.9 & 157 & 1.11 & $\mathrm{C} 26$ & 12200 & 0.83 & $\mathrm{C} 71$ \\
\hline U & 240.5 & 26.1 & 4.53 & C1 & 1510 & 1.8 & C71 \\
\hline $\mathrm{Sb}$ & 1023.7 & 52.6 & 10.5 & C9 & 3560 & 0.87 & $\mathrm{C} 1$ \\
\hline Sn & 60700.0 & 12600 & 0.81 & C17 & 394000 & 0.3 & C46 \\
\hline $\mathrm{Hg}$ & 0.9 & $\mathrm{BDL}$ & & $\mathrm{C} 17$ and $\mathrm{C} 37$ & 16.45 & 5.03 & C55 \\
\hline
\end{tabular}

Table 5: The concentration of elements on the Base jelly samples in ppb.

\begin{tabular}{|c|c|c|c|c|c|c|c|}
\hline \multirow{2}{*}{ Elements } & \multicolumn{7}{|c|}{ Whitener } \\
\hline & Mean of four brands & Min & RSD & Samples & Max & RSD & Samples \\
\hline $\mathrm{Li}$ & 14491.9 & 67.4 & & C36 & 29000 & 1.43 & $\mathrm{C} 45$ \\
\hline B & & BDL & & C36, C45, C53 & 9550000 & 0.68 & $\mathrm{C} 25$ \\
\hline $\mathrm{Na}$ & 2405500.0 & 352000 & 1.14 & $\mathrm{C} 53$ & 6150000 & 0.34 & $\mathrm{C} 45$ \\
\hline $\mathrm{Mg}$ & 934325.0 & 46300 & 3.67 & $\mathrm{C} 36$ & 3200000 & 1.54 & $\mathrm{C} 45$ \\
\hline $\mathrm{Al}$ & 3196325.0 & 75300 & 1.22 & $\mathrm{C} 36$ & 8010000 & 0.44 & $\mathrm{C} 25$ \\
\hline K & 1260250.0 & 138000 & 0.88 & $\mathrm{C} 36$ & 4260000 & 0.95 & $\mathrm{C} 25$ \\
\hline $\mathrm{Ca}$ & 233650.0 & $\mathrm{BDL}$ & & C36 and C53 & 454000 & 2.99 & $\mathrm{C} 25$ \\
\hline V & 576.4 & 87.4 & 4.90 & $\mathrm{C} 36$ & 1540 & 1.56 & $\mathrm{C} 25$ \\
\hline
\end{tabular}


Citation: $\quad$ Aldayel O, Hefne J, Alharbi KN, Al-Ajyan T (2018) Heavy Metals Concentration in Facial Cosmetics. Nat Prod Chem Res 6: 303. doi:

Page 6 of 9

\begin{tabular}{|c|c|c|c|c|c|c|c|}
\hline $\mathrm{Cr}$ & 1670.0 & 1040 & 6.08 & C36 & 2290 & 0.51 & C45 \\
\hline Mn & 2250.5 & 115 & 8.11 & C36 & 5790 & 1.32 & $\mathrm{C} 25$ \\
\hline $\mathrm{Fe}$ & 218925.0 & 22600 & 5.31 & C36 & 613000 & 0.86 & $\mathrm{C} 25$ \\
\hline Co & 111.0 & 53.7 & 2.80 & C53 & 204 & 2.70 & $\mathrm{C} 45$ \\
\hline $\mathrm{Ni}$ & 2897.0 & $\mathrm{BDL}$ & & C53 & 12500 & 1.37 & $\mathrm{C} 45$ \\
\hline $\mathrm{Cu}$ & 7466.7 & $\mathrm{BDL}$ & & C36 & 13600 & 2.83 & C53 \\
\hline $\mathrm{Zn}$ & 17425.0 & 1900 & 5.48 & C36 & 42600 & 1.64 & C53 \\
\hline As & 236.0 & 97 & 13.20 & C53 & 544 & 1.85 & $\mathrm{C} 45$ \\
\hline $\mathrm{Se}$ & 308.5 & 55 & & $\mathrm{C} 36$ & 1020 & & $\mathrm{C} 45$ \\
\hline $\mathrm{Rb}$ & 7740.1 & 90.5 & 4.11 & $\mathrm{C} 36$ & 25100 & 0.64 & $\mathrm{C} 25$ \\
\hline $\mathrm{Sr}$ & 1546.7 & BDL & & $\mathrm{C} 36$ & 2050 & 0.74 & $\mathrm{C} 45$ \\
\hline Mo & 275.5 & 124 & 8.41 & $\mathrm{C} 25$ & 663 & 2.18 & $\mathrm{C} 45$ \\
\hline $\mathrm{Ag}$ & 33.7 & 13.7 & 15.50 & $\mathrm{C} 36$ & 64.1 & 3.59 & C53 \\
\hline $\mathrm{Cd}$ & 30.8 & 12.4 & 18.70 & $\mathrm{C} 25$ & 68.5 & 16.30 & $\mathrm{C} 45$ \\
\hline $\mathrm{Ba}$ & 5093.5 & 374 & 7.53 & $\mathrm{C} 36$ & 12300 & 0.75 & $\mathrm{C} 25$ \\
\hline $\mathrm{Pb}$ & 557.8 & 104 & 0.30 & $\mathrm{C} 36$ & 954 & 1.28 & $\mathrm{C} 25$ \\
\hline$U$ & 283.4 & 92.5 & 4.39 & C53 & 833 & 1.99 & $\mathrm{C} 45$ \\
\hline $\mathrm{Sb}$ & 98.1 & BDL & & C36 & 173 & 5.06 & C45 \\
\hline Sn & 20250.0 & 16500 & 0.43 & C36 & 27900 & 0.68 & $\mathrm{C} 25$ \\
\hline $\mathrm{Hg}$ & 0.3 & 0.04 & 8.10 & C36 & 0.61 & 1.80 & C53 \\
\hline
\end{tabular}

Table 6: The concentration of elements on the whitener samples in ppb.

\begin{tabular}{|c|c|c|c|c|c|c|c|}
\hline \multirow[t]{2}{*}{ Elements } & \multicolumn{7}{|c|}{ Sheen } \\
\hline & Mean of nine brands & Min & RSD & Samples & Max & RSD & Samples \\
\hline $\mathrm{Li}$ & 31287.9 & 931 & 8.21 & C33 & 162000 & 1.83 & C51 \\
\hline B & 11995.7 & BDL & & $\mathrm{C} 42$ and $\mathrm{C} 60$ & 24700 & 3.88 & $\mathrm{C} 22$ \\
\hline $\mathrm{Na}$ & 421888.9 & 216000 & 1.71 & C33 & 875000 & 1.97 & $\mathrm{C} 22$ \\
\hline $\mathrm{Mg}$ & 594966.7 & 30700 & 3.57 & $\mathrm{C} 42$ & 2770000 & 0.23 & C51 \\
\hline $\mathrm{Al}$ & 4935555.6 & 1760000 & 0.90 & $\mathrm{C} 42$ & 9860000 & 1.06 & $\mathrm{C} 22$ \\
\hline $\mathrm{K}$ & 1936666.7 & 408000 & 1.48 & $\mathrm{C} 33$ & 4630000 & 1.27 & $\mathrm{C} 22$ \\
\hline $\mathrm{Ca}$ & 6895375.0 & BDL & & $\mathrm{C} 6, \mathrm{C} 14, \mathrm{C} 22$ and $\mathrm{C} 76$ & 27300000 & 0.68 & $\mathrm{C} 33$ \\
\hline V & 1215.6 & 208 & 3.22 & $\mathrm{C} 42$ & 4180 & 1.15 & $\mathrm{C} 14$ \\
\hline $\mathrm{Cr}$ & 1927.8 & 1020 & 7.17 & $\mathrm{C} 68$ & 3490 & 2.30 & $\mathrm{C} 14$ \\
\hline $\mathrm{Mn}$ & 7156.7 & 1080 & 1.68 & $\mathrm{C} 42$ & 21500 & 0.84 & C14 \\
\hline $\mathrm{Fe}$ & 2075888.9 & 311000 & 1.57 & C51 & 9280000 & 1.19 & C14 \\
\hline
\end{tabular}


Citation: $\quad$ Aldayel O, Hefne J, Alharbi KN, Al-Ajyan T (2018) Heavy Metals Concentration in Facial Cosmetics. Nat Prod Chem Res 6: 303. doi:

Page 7 of 9

\begin{tabular}{|c|c|c|c|c|c|c|c|}
\hline Co & 247.4 & 63.9 & 5.92 & C68 & 810 & 10.60 & C33 \\
\hline $\mathrm{Ni}$ & 1456.2 & BDL & & $\mathrm{C} 14, \mathrm{C} 22,51$ and 60 & 2590 & 1.28 & C76 \\
\hline $\mathrm{Cu}$ & 21494.4 & 510 & 5.62 & C42 & 177000 & 0.76 & C33 \\
\hline $\mathrm{Zn}$ & 59371.7 & BDL & & C6, C14 and C42 & 163000 & 0.21 & $\mathrm{C} 60$ \\
\hline As & 219.1 & BDL & & C76 & 853 & 4.28 & C33 \\
\hline Se & 142.3 & BDL & & C14, C22, C51 and C68 & 224 & 20.30 & $\mathrm{C} 60$ \\
\hline $\mathrm{Rb}$ & 15096.7 & 3690 & 0.46 & C33 & 33700 & 0.69 & $\mathrm{C} 22$ \\
\hline $\mathrm{Sr}$ & 8483.0 & 55.7 & 8.72 & C42 & 52900 & 0.60 & C33 \\
\hline Mo & 168.9 & BDL & & $\mathrm{C} 68$ and $\mathrm{C} 76$ & 228 & 5.05 & $\mathrm{C} 33$ \\
\hline $\mathrm{Ag}$ & 35.4 & BDL & & C22, C42 and C51 & 76 & 4.15 & $\mathrm{C} 33$ \\
\hline $\mathrm{Cd}$ & 8.9 & BDL & & C14, C68 and C76 & 19.8 & 12.50 & C33 \\
\hline $\mathrm{Ba}$ & 534331.1 & 3870 & 1.99 & C42 & 4240000 & 0.84 & $\mathrm{C} 33$ \\
\hline $\mathrm{Pb}$ & 3114.2 & 190 & 1.22 & C42 & 22500 & 0.29 & $\mathrm{C} 33$ \\
\hline U & 95.7 & BDL & & C68 & 288 & 1.29 & C33 \\
\hline $\mathrm{Sb}$ & 39.7 & 4.1 & 67.20 & C6 & 107 & 2.87 & C33 \\
\hline Sn & 26911.1 & 17200 & 1.64 & C68 & 46800 & 1.26 & $\mathrm{C} 33$ \\
\hline $\mathrm{Hg}$ & 12.6 & $\mathrm{BDL}$ & & $\mathrm{C} 6, \mathrm{C} 14$ and $\mathrm{C} 22$ & 52.1 & & C51 \\
\hline
\end{tabular}

Table 7: The concentration of elements on the Sheen samples in ppb.

\begin{tabular}{|c|c|c|c|c|c|c|c|}
\hline \multirow[t]{2}{*}{ Elements } & \multicolumn{7}{|c|}{ Face Powder } \\
\hline & Mean of eight brands & Min & RSD & Samples & Max & RSD & Samples \\
\hline $\mathrm{Li}$ & 17995.9 & 161 & 1.36 & $\mathrm{C} 78$ & 63700 & 0.78 & C62 \\
\hline B & 1345945.9 & $\mathrm{BDL}$ & & $\mathrm{C} 35,70$ and 78 & 10700000 & 1.51 & $\mathrm{C} 24$ \\
\hline $\mathrm{Na}$ & 944625.0 & 289000 & 1.52 & C35 & 2570000 & 0.40 & $\mathrm{C} 24$ \\
\hline $\mathrm{Mg}$ & 13602500.0 & 4070000 & 0.43 & $\mathrm{C} 78$ & 26300000 & 1.04 & C44 \\
\hline $\mathrm{Al}$ & 10111500.0 & 374000 & 0.35 & $\mathrm{C} 78$ & 31000000 & 0.59 & $\mathrm{C} 24$ \\
\hline K & 10165637.5 & 15100 & 4.20 & $\mathrm{C} 8$ & 29100000 & 1.07 & $\mathrm{C} 24$ \\
\hline $\mathrm{Ca}$ & 2768625.0 & 420000 & 3.16 & $\mathrm{C} 24$ & 11600000 & 0.57 & C62 \\
\hline V & 5216.3 & 1420 & 2.01 & $\mathrm{C} 70$ & 15700 & 0.77 & $\mathrm{C} 24$ \\
\hline $\mathrm{Cr}$ & 3400.0 & 1780 & 2.02 & C16 & 5510 & 1.19 & C35 \\
\hline $\mathrm{Mn}$ & 46725.0 & 22200 & 1.07 & C8 & 117000 & 0.46 & $\mathrm{C} 24$ \\
\hline $\mathrm{Fe}$ & 4391250.0 & 1210000 & 1.52 & $\mathrm{C} 78$ & 8780000 & 0.42 & $\mathrm{C} 70$ \\
\hline Co & 2248.9 & 488 & 2.23 & $\mathrm{C} 70$ & 5350 & 1.38 & C35 \\
\hline $\mathrm{Ni}$ & 6557.7 & 41.4 & & $\mathrm{C} 24$ & 22300 & 1.90 & C35 \\
\hline $\mathrm{Cu}$ & 6829.5 & $\mathrm{BDL}$ & & $\mathrm{C} 24$ & 20300 & 1.44 & $\mathrm{C} 70$ \\
\hline
\end{tabular}




\begin{tabular}{|c|c|c|c|c|c|c|c|}
\hline $\mathrm{Zn}$ & 5429993.8 & 2120 & 3.31 & C16 & 24400000 & 0.83 & $\mathrm{C} 70$ \\
\hline As & 441.9 & 156 & 11.70 & $\mathrm{C} 8$ & 793 & 6.62 & C35 \\
\hline $\mathrm{Se}$ & 1483.8 & 514 & 15.80 & C8 & 4450 & 13.40 & C44 \\
\hline $\mathrm{Rb}$ & 53434.9 & 399 & 5.46 & $\mathrm{C} 8$ & 185000 & 0.57 & C62 \\
\hline $\mathrm{Sr}$ & 5108.3 & 622 & 1.46 & $\mathrm{C} 70$ & 24400 & 0.38 & $\mathrm{C} 24$ \\
\hline Mo & 382.8 & BDL & & $\mathrm{C} 70$ & 1210 & 2.97 & C35 \\
\hline $\mathrm{Ag}$ & 283.6 & 31.4 & 11.50 & C62 & 1600 & 2.13 & $\mathrm{C} 24$ \\
\hline $\mathrm{Cd}$ & 47.1 & 4.63 & & C16 & 155 & 12.40 & $\mathrm{C} 24$ \\
\hline $\mathrm{Ba}$ & 41846.3 & 2220 & 1.22 & $\mathrm{C} 70$ & 157000 & 1.06 & $\mathrm{C} 24$ \\
\hline $\mathrm{Pb}$ & 4194.3 & 934 & 2.33 & $\mathrm{C} 8$ & 7710 & 0.73 & $\mathrm{C} 62$ \\
\hline U & 1789.8 & 91.2 & 2.13 & $\mathrm{C} 70$ & 3250 & 1.07 & C35 \\
\hline $\mathrm{Sb}$ & 774.4 & 71 & 16.40 & C16 & 2650 & 0.81 & $\mathrm{C} 24$ \\
\hline Sn & 31337.5 & 17900 & 0.28 & C16 & 65100 & 0.31 & C44 \\
\hline $\mathrm{Hg}$ & 2.8 & BDL & & C8, C16, C24, C35, C44 and C78 & 5.2 & 0.98 & C62 \\
\hline
\end{tabular}

Table 8: The concentration of elements on the Face Powder samples in ppb.

When compared to the mean concentration of elements in the facial cosmetics samples (base jelly, whitener, sheen and face powder) under investigation, we observed:

The mean concentration of elements in whitener samples were the lowest among the fifteen elements (Li, B, Al. V, Cr, Mn, Fe, Co, Zn, Sr, $\mathrm{Ag}, \mathrm{Ba}, \mathrm{Pb}, \mathrm{Sn}$ and $\mathrm{Hg}$ ). In this work whitener samples do not record any element with highest mean concentration. Face powder samples record the highest mean concentration of the sixteen elements $(\mathrm{B}, \mathrm{Mg}$, $\mathrm{Al}, \mathrm{K}, \mathrm{V}$. Mn, Co, Zn, As, Se, Rb, Mo, Ag, Cd, Pb and U). Only one element, copper, in face powder samples showed the lowest mean concentration. Base jelly samples had three elements with the lowest mean concentration ( $\mathrm{K}, \mathrm{Ca}$ and $\mathrm{Rb})$ and six elements with the highest mean concentration ( $\mathrm{Na}, \mathrm{Cr}, \mathrm{Fe}, \mathrm{Ni}, \mathrm{Sb}$ and $\mathrm{Sn}$ ). Sheen samples had nine elements with the lowest mean concentration ( $\mathrm{Na}, \mathrm{Mg}, \mathrm{Ni}, \mathrm{As}, \mathrm{Se}$, $\mathrm{Mo}, \mathrm{Cd}, \mathrm{U}$ and $\mathrm{Sb}$ ) and six elements with the highest mean concentration ( $\mathrm{Li}, \mathrm{Ca}, \mathrm{Cu}, \mathrm{Sr}, \mathrm{Ba}, \mathrm{Hg}$ ).

\section{Conclusion}

It is acknowledged that heavy metal impurities in cosmetic products are unavoidable due to the ubiquitous nature of these elements, but should be removed wherever technically feasible.

Cosmetic in general can have a high concentration of trace-metal elements. Given the significant and relatively uncontrolled human exposure to cosmetics and their ingredients, these products must be thoroughly evaluated for their safety prior to marketing [50-54].

\section{Acknowledgment}

The authors would like to acknowledge King Abdulaziz City for Science and Technology (KACST) for financially supporting this work and Professor Sayed Gary for revising this paper.

\section{References}

1. Zakaria A, Bin Ho Y (2015) Heavy metals contamination in lipsticks and their associate health risk to lipstick consumers. Regul Toxicol Pharmacol 73: 191-195.

2. Glanze WD (1996) Mosby Medical Encyclopedia, Revised Edition. St. Louis MO, CV Mosby, Missouri, USA.

3. International Labour Organization-ILO (1999) International Occupational Safety and Health Information Centre. Metals, Geneva.

4. Campaign for Safe Cosmetics (2007) A Poison Kiss: The Problem of Lead in Lipstick.

5. Bo Y (2009) Toxic substances found in cosmetics for children. Green Planet.net.

6. European Union Consumer Affairs (2008) Rapid Alert System for Non Products.

7. Sarah S (2010) Heavy metals found in kids' face paints. Canwest News Service.

8. Farley $\mathrm{T}$ (2010) Lead poisoning prevention program. New York.

9. Ullah H, Noreen S, Ali Rehman F, Waseem A, Zubai S, et al. (2017) Comparative study of heavy metals content in cosmetic products of different countries marketed in Khyber Pakhtunkhwa, Pakistan. Arabian J Chem 10: 10-18.

10. Klassen CD (2001) Casarett and Doull's Toxicology-The basic science of poisons. 8th edn. New York: McGraw-Hill, p: 827.

11. Bernardi RA (2002) Protect children from the dangers of lead. HUD announces \$10 million to help communities. HUD No. 02-022.

12. Al-Saleh ZI, Khalil MA, Taylor A (1995) Lead, erythrocyte protoporphyrin, and hematological parameters in normal maternal and umbilical cord blood from subjects of the Riyadh region, Saudi Arabia. Arch Environ Health 509: 66-73.

13. Rothenberg SJ, Schnaas L, Zalgado-Valladares M (2002) Increased ERG a and $\mathrm{b}$ wave amplitudes in 7 to 10 year old children resulting from prenatal lead exposure. Invest Ophthalmol Vis Sci 43: 2036-3044.

14. Al-Saleh I (1998) Heavy metal concentrations in the breast milk of Saudi women. J Environ Pathol Toxicol Oncol 17: 17-35. 
15. Sonmez F, Donmez O, Sonmez HM, Keskinoglu C, Kabasakal C (2002) Lead exposure and urinary $\mathrm{N}$-acetyl beta $\mathrm{D}$ glucosaminidase activity in adolescent workers in auto repair workshops. J Adolesc Heal 30: 213-216.

16. $\mathrm{Hu} \mathrm{H}$ (2001) Poorly-controlled hypertension in a painter with chronic lead toxicity. Environ Heal Perspect 109: 95-99.

17. Shaltout A, Yaish SA, Fernando N (1981) Lead encephalopathy in infants in Kuwait. A study of 20 infants with particular reference to clinical presentation and source of lead poisoning. Ann Trop Paediatr 1: 209-215.

18. Farley D, Alert FC (1998) Dangers of lead still linger. FDA Consumer 32: 16.

19. US Food and Drug Administration (2001) Cosmetics and Colors Fact Sheet. Washington, DC: US Food and Drug Administration Center for Food Safety and Applied Nutrition, Office of Cosmetics and Colors Fact Sheet, pp: 30.

20. Al Khawajah AM (1992) Alkohl use in Saudi Arabia. Extent of use and possible lead toxicity. Trop Geogr Med 44: 373-377.

21. Al-Saleh I, Nester M, Devol E, Shinwari N, Al-Shahria S (1999) Determinants of blood lead levels in Saudi Arabian schoolgirls. Int J Occup Environ Heal 5: 107-114.

22. Hinds'en M, Spir'en A, Bruze M (2005) Cross-reactivity between nickel and palladium demonstrated by systemic administration of nickel. Contact Dermat 53: 2-8

23. Santucci B, Valenzano C, De Rocco M, Cristaudo A (2000) Platinum in the environment: frequency of reactions to platinum-group elements in patients with dermatitis and urticaria. Cont Dermat 43: 333-338.

24. Marcusson JA, Cederbrant K (1998) Indium and iridium allergy in patients exposed to dental alloys. J Heilborn Cont Dermat 38: 297-298.

25. Hostynek JJ, Maibach HI (2004) Copper hypersensitivity: dermatologic aspects. Dermatol Ther 17: 328-333.

26. Pardo J, Rodr'1guez-Serna M, De La Quadra J, Fortea JM (2004) Allergic Contact Stomatits due to Manganese in Dental Prosthesis. Cont Dermat 50: 41.

27. Isikli B, Demir TA, Akar T, Berber A, Urer SM, et al. (2006) Cadmium exposure from the cement dust emissions: A field study in a rural residence. Chemos 63: 1546-1552.

28. Motolese A, Truzzi M, Giannini A, Seidenari S (1993) Contact dermatitis and contact sensitization among enamellers and decorators in the ceramics industry. Cont Dermat 28: 59-62.

29. Sun CC (1987) Allergic contact dermatitis of the face from contact with nickel and ammoniated mercury in spectacle frames and skin-lightening creams. Contact Dermat 17: 306-309.

30. Anon M (1976) Directive 76/768/EEC of 27 July 1976 on the approximation of the laws of the Member States relating to cosmetic products. Offic J Europ Commu 262: 169-200.

31. Kang LJ, Lee MH (2006) Quantification of para-phenylenediamine and heavy metals in henna dye. Contact Dermat 55: 26-29.

32. Allenby CF, Basketter DA (1993) An arm immersion model of compromised skin (II), Influence on minimal eliciting patch test concentrations of nickel. Contact Dermat 28: 129-133.

33. Sainio EL, Jolanki R, Hakala E, Kanerva L (2000) Metals and arsenic in eye shadows. Contact Dermat 42: 5-10.

34. Ahmed KS (2016) Assessment of metals in cosmetic commonly used in Saudi Arabia. Environ Monit Assess 188: 553.
35. Lekouch N, Sedki A, Nejmeddine A, Gamon S (2001) Lead and traditional Moroccan pharmacopoeia. Total Environ 280: 39-43.

36. Jager C, Jappe U, Dtsch J (2005) Contact dermatitis to permanent makeup: manifestation of a pre-existing nickel allergy in German. Dermatol Ges 3: 527-529.

37. Tsankov I, Iordanova I, Lolova D, Uzunova S, Dinoeva S (1982) Hygienic evaluation of the content of heavy metals (lead and copper) in cosmetic products. Probl Khig 7: 127-136.

38. Salvador A, Pascual-Mart'i MC, Adell JR, Requeni A, March JC (2000) Analytical methodologies for atomic spectrometric determination of metallic oxides in UV sunscreen creams. J Pharm Biomed Anal 22: 301-306.

39. Conti ME, Botr'e F, Mazzei F (1996) On the heavy metals content in cosmetic formulations: An atomic absorption spectroscopy investigation. J Appl Cosmetol 14: 147-154.

40. Bocca B, Forte G, Petrucci F, Cristaudo A (2007) Levels of nickel and other potentially allergenic metals in Ni-tested commercial body creams. J Pharm Biomed Anal 44: 1197-1202.

41. Darbre Eur PD (2001) Underarm cosmetics are a cause of breast cancer. J Cancer Prev 10: 389-393.

42. Darbre PD (2003) Underarm cosmetics and breast cancer. J Appl Toxicol 23: 89-95.

43. Harvey PW, Darbre P (2004) Endocrine disrupters and human health: could oestrogenic chemicals in body care cosmetics adversely affect breast cancer incidence in women. J Appl Toxicol 24: 167-176.

44. Laden K, Felger CB (1988) Anti perspirants and Deodorants: Cosmetic Science and Technology Series, 7.

45. Habs H, Simon B, Thiedemann KU, Howe P (1997) Environmental Health Criteria: Aluminium, World Health Organization, p: 194.

46. http://www.inchem.org/documents/ehc/ehc/ehc194.htm.

47. Yokel RA, McNamara PJ (2001) Aluminium Toxicokinetics: An Updated Mini Review. Pharmacol Toxicol 88: 159-167.

48. Exley C (2001) Aluminium and Alzheimers Disease: The Science that Describes the Link. Elsevier.

49. Salvador A, Pascual-Martı MC, Arago E, Chisvert A, March JG (2000) Determination of selenium, zinc and cadmium in antidandruff shampoos by atomic spectrometry after microwave assisted sample digestion. Talanta 51: 1171-1177.

50. https://www.canada.ca/en/health-canada.html.

51. Al-Ashban RM, Aslam M, Shah AH, Kohl S (2004) A toxic traditional eye cosmetic study in Saudi Arabia. Public Heal 118: 292.

52. Funtua I, Oyewale AO (1997) Elemental composition of traditional eye make-up (kwali) in Nigeria. J Chem Soc Nigeria 22: 160-163.

53. Ajayi SO, Oladipo MO, Ogunsuyil HO, Adebayo AO (2002) Determination of the minor and trace elements in biriniwa's tin pyrite and ornamental lead/zinc ore using neutron activation analysis. Bull Chem Soc Ethiopia 16: 207.

54. Bocca B, Pino A, Alimonti A, Forte G (2014) Toxic metals contained in cosmetics: A status report. Regulat Toxicol Pharmacol 68: 447-467. 